\title{
Investigating the Correlation between the Frequency of Using Metacognitive Reading Strategies and Non-routine Problem Solving Successes in Fifth Grade Students
}

\author{
Sevil Büyükalan Filiz ${ }^{1}$, Mustafa Erol ${ }^{2, *}$, Ahmet Erol ${ }^{3}$ \\ ${ }^{1}$ Department of Educational Sciences, Faculty of Education, Gazi University, Ankara, Turkey \\ ${ }^{2}$ Department of Elementary Education, Faculty of Education, Yıldız Technical University, İstanbul, Turkey \\ ${ }^{3}$ Department of Elementary Education, Faculty of Education, Pamukkale University, Denizli, Turkey
}

Copyright $\mathrm{O} 2018$ by authors, all rights reserved. Authors agree that this article remains permanently open access under the terms of the Creative Commons Attribution License 4.0 International License

\begin{abstract}
The aim of this study is to examine the correlation between the frequency of using metacognitive reading strategy use and non-routine problem-solving achievements in fifth grade students. The study was conducted by using the correlational survey model, one of quantitative research methods. The participants of the study consisted of 308 fifth grade students who were studying in public schools in Istanbul and Ankara in 2017-2018 school year and were selected with convenient sampling method. The data of the study were gathered using the form for the frequency of using metacognitive reading strategy by the students and the non-routine problem solving achievement Test. In the study, the form for the frequency of using metacognitive reading strategy was applied in order to determine metacognitive reading strategies of the studies and on the following day, the achievement test including non-routine problems was then applied to the students. Simple Linear Regression Analysis and Pearson Product-Moments Correlation Analysis were used in the analysis of the data obtained in the study. According to the results of the study, there was a positive correlation between the frequency of using metacognitive reading strategy and non-routine problem-solving achievements in fifth grade students and metacognitive reading strategies were a predictor of non-routine problem-solving achievement.
\end{abstract}

Keywords Metacognitive Reading Strategies, Non-routine Problems

\section{Introduction}

Individuals need to primarily trust themselves and to produce solutions in order to solve the problems in their education life [35]. In order to solve problems, students should be aware of their mental process. It is possible to train conscious individuals in education by ensuring that individuals are aware of their potentials [14] because effectiveness and permanence of learning is associated with its conscious performance [25]. The concept of metacognition signifies the awareness of the students about what they learn. Metacognition is generally defined as knowing the structure and working principles of one's own cognitive system (mental activities involved in perception, remembering, and thinking) and the ability to control them $[32,18,35]$. It is stated in the literature that students need to use metacognitive strategies in order for them to understand difficult texts and develop reading competence during the reading process [21]. This is because the metacognitive reading strategies are defined as the conscious mental behaviors that include selection, execution, direction, and control of cognitive strategies [29].

The reading comprehension skills of the students are important not only in Turkish lesson but also in all lessons [10]. At this point, reading comprehension in mathematical problem solving and the metacognitive awareness of the student in this subject can facilitate the solution of the problem. However, the skills of solving mathematical problems are known to be an important issue in formal education environment [17]. In particular, the solution of problems outside certain routines can be a source of problems for students. The main feature of these problems challenging for the students can be that the problem cannot be understood completely by the student. In this context, it can be asserted that reading and understanding strategies used by the students are important for solving mathematical problems because non-routine problems involve the use of some mental 
strategies unlike the solution of routine problems requiring algorithm [15].

The problem is that a person wants to do something but does not know immediately what to do [2]. Problem solving is choosing the most effective one among tools and behaviors used to reach the desired goal [28]. Students need to be aware of what they need to do in order to learn to solve mathematical problems, to establish new connections, and to comprehend mathematical thinking [39]. In the solution of the problems, the person is expected to believe him/herself, develop sense of success, cope with complex problems and develop metacognitive reading strategies in order to try out different approaches in problem solving and establish his/her own solution logic [35].

Many students have inadequate belief and attitude concerning mathematical problem solving. These beliefs affect adversely students' desire to solve a mathematical problem. Some examples of such beliefs and attitudes are only one right way to solve a problem, the thought of presence of a single correct solution for a mathematical problem, and prejudices of students against non-routine problems. In addition, students often face with routine problems that require only basic operations and calculations. This also affects the attitudes of the students [3]. Non-routine problems are the problems including more intellectual processes for solution and unclear solution compared to the routine ones and contains more intellectual processes for solution [30].

Problem solving skills include using the knowledge differently, acquiring new information, and developing different problem solving methods [22]. De Hoys, Gray, and Simpson [13] examined the non-routine problem solving skills of the students learning two languages and determined that while the successful students developed a different method according to the characteristics of the problem, the other tried to choose a useful one among current methods. In addition, the use of non-routine problems in problem solving increases significantly the person's abilities [31] because creative thinking, critical thinking, and information transfer have an important place in problem solving.

Numerous studies on problem solving and development of solutions have been conducted in the literature. Yazgan [42] showed in his study entitled "Observations about Non-routine Problem Solving Strategies of Fourth and Fifth Graders" that the students can comprehend non-routine problem solving strategies. Ulu, Tertemiz \& Peker [37] emphasized in their study that the training on reading comprehension skills increased non-routine problem solving skills of the students and reading comprehension studies should be included in the training of problem solving. Likewise, Hite [19] determined that the students cannot solve the four operation problems and applied the reading comprehension test to them since this was associated with reading comprehension. Consequently, they found out that the reading comprehension skills of the students were low. In order to increase the problem solving success of the students, the training on reading comprehension was given to them to solve the problems better. It is possible to assert that reading comprehension enhance the academic success [12].

\subsection{Purpose of the Study}

When the national literature is examined, it is seen that there are studies indicating the students' metacognitive reading strategies $[1,6,7]$ and problem solving and non-routine problem solving skills [4, 37, 41]. However, there is no study on the metacognitive reading strategies and non-routine problem-solving skills of the students in literature. Based on the opinion that reading comprehension and metacognitive reading skills support each other in terms of the mathematical problem solving skills and mental processes, this study was aimed to investigate the correlation between the frequencies of using metacognitive reading strategies and non-routine problem solving successes in students. In accordance with this purpose, the problem sentence of the study was determined as "Is there any significant correlation between the frequency of using metacognitive reading strategies and non-routine problem solving successes in fifth grade students?" When the literature is examined, it is seen that the metacognitive reading strategies are intensively studied but there is a limited number of the studies on non-routine problem solving. In this respect, the results of the study are expected to shed light on future studies.

In accordance with the purpose of this study, answers to the following sub-objectives were sought.

- How are the fifth grade students' frequencies of using metacognitive reading strategies?

- How are metacognitive reading levels of fifth grade students?

- How is the correlation between the frequencies of using metacognitive reading strategies and the non-routine problem solving successes in fifth grade students?

- Do metacognitive reading strategies predict their non-routine problem solving successes in fifth grade students?

\section{Materials and Methods}

\subsection{Model of the Research}

This study was conducted within the context of a correlational survey study, one of quantitative study designs. Studies examining the correlations and connections between different variables are called as correlational studies [9]. Studies aiming to determine participants' opinions or characteristics such as interest, skills, abilities, and attitude etc. concerning a subject or an 
event and being generally conducted with larger samples are called as survey study [8]. Survey studies can be conducted in two designs as cross-sectional and longitudinal. This study was conducted within the scope of the cross-sectional survey research. Christensen, Burke Johnson \& Turner [11] defined cross-sectional survey study as the researches where the data are collected for only once from the participants in the sample within a relatively short time period. Although the data are collected only once in these studies, it is easier to generalize since a large sample is studied. This study was conducted using correlational survey model since it investigated the correlation between the frequency of using metacognitive reading strategy and non-routine problem solving achievements in students

\subsection{The participants of the Study}

The participants of the study consisted of a total of 308 fifth grade students including 184 girls (59.7\%) and 124 boys (40.3\%) being selected with convenient sampling method and studying in schools affiliated with the Directorates of National Education in Istanbul (a total of 188 students including $114(60.6 \%)$ girls and 74 (39.4\%) boys) and Ankara (a total of 120 students including 70 (53.3\%) girls and 50 (41.7\%) boys). Convenient sampling method can be utilized to minimize time, effort and cost loss and to bring speed and practicability to the study [21, 43]. The data were collected by applying the questionnaire for frequencies of using metacognitive reading strategies and non-routine problem solving achievement test to a total of 308 students.

\subsection{Data Collection}

Personal Information Form: The personal information form was prepared by the researcher to know the sample group better and analyze the factors which were thought to have effects on the study. In the personal information form, the items like the participants' gender, their ages, their parents' educational level, ages, and occupations, and their siblings' number and gender were examined in order to know the sample group well.

Questionnaire for Frequency of Using Metacognitive Reading Strategy (FMRSU-Q): Developed by Başaran [6]. The researcher developed this questionnaire based on the metacognitive reading strategies questionnaire, outlined in conceptual framework and developed by Taraban, Rynearson and Kerr [34] and Mokdari and Reichard [24]. The questionnaire consists of four subscales. The first subscale includes the metacognitive reading strategies to be used before reading, the second subscale includes the metacognitive reading strategies to be used during reading, the third subscale includes the metacognitive reading strategies to be used after reading, and the last subscale includes the metacognitive reading strategies to be used for recalling. Once the items prepared were examined by two 4th grade primary education teachers and three field experts in terms of appropriateness to the levels of the students and serving for the aim of measurement, the questionnaire was finalized. The validity of the questionnaire was provided acquiring expert opinions. Since the overall questionnaire or its subscales do not have a factorial structure, factor analysis and internal consistency processes were not performed in reliability studies. In this study, Cronbach's Alpha coefficients of the Metacognitive Reading Strategy Questionnaire were .70 for the first subscale, .89 for the second subscale, .74 for the third subscale, and .81 for the last subscale.

Non-routine Problem Solving Achievement Test: Non-routine Problem Solving Achievement Test was developed by Ulu [38]. Firstly, the researcher prepared a question pool with 52 items and developed three achievement tests with 12 questions. Since the first achievement test intends to determine the errors made by students in non-routine problems and the causes of their errors, the third achievement test is prepared in parallel with the second test namely without not changing the questions and only changing the order of numbers in the questions, the second achievement test is preferred for the research. The tests are decided to include 12 questions for the attention level of the students, the number of questions likely to be solved by the students during a lesson (45 minutes), and examination of 4 schemas (comparison, combination, equation and conversion) with equal number of questions. When examining the results about the reliability and validity of the second non-routine problem solving achievement test (ROPCBT2), the $27 \%$ (39) upper group receiving the highest score and $27 \%$ (39) lower group receiving the lowest score were determined among the all students in item analysis studies, the group with $46 \%$ (67) having moderate achievement level was not included into the analysis. It was observed that the difficulty indices of the items in the test (pj) varied between 0.30 and 0.47 and item discrimination indices (rjx) varied between 0.53 and 0.76 . Furthermore, the KR20 internal consistency value of the test was determined as 0.88 . Kr20 internal consistency coefficient for this study was determined as .83 .

\subsection{Data Collection Process}

In the study, the data were collected from public schools affiliated with the provincial directorates of national education in Istanbul and Ankara. The necessary permissions were obtained from directorates of national education before the data collection process. Moreover, the students who participated in the study were determined on the basis of volunteerism. A total of three hundred and ninety students were reached in the study. The students who were not voluntary and did not answer the questionnaires or gave the same answer several times were not included in the study. At the end of the data collection process, the sample of the study consisted of three hundred and eight students. 


\subsection{Data Analysis}

Before starting the data analysis, the kurtosis and skewness coefficients were examined to determine whether the data were normally distributed or not. They were determined to distribute between -.36 and -.05 before reading for better understanding, -.42 and -.06 during reading for better understanding, -.76 and .30 after reading for better understanding, -.37 and -.33 for recalling and 1.40 and 1.36 for the Non-routine Problem Solving Achievement Test. Fidell and Tabachnick [16] indicate that the kurtosis and skewness values ranging from -1.5 to +1.5 would meet the normality assumption. According to this criterion, it can be asserted that the data set to be used in the study showed a normal distribution. Accordingly, Simple Linear Regression Analysis, Multiple Linear Regression Analysis, and Pearson Product-Moment Correlation Analysis were used.

In the study, autocorrelation (Durbin Watson coefficient) was calculated as 1.53 for auto-control among the assumptions of multiple regression analysis. Kalayc [20] states that the autocorrelation coefficient is expected to be between 1.5 and 2.5. In addition, normal distribution and linearity with children were tested with Histogram and normal probability plot and it was seen that there was no multiple connection between the independent variables and there was a linear correlation between the dependent and independent variables.

\section{Results}

In this section, the results obtained in the study were presented and interpreted in tabular form. Accordingly, the most and the least used metacognitive reading strategies by the students were determined. Table 1 shows the results.

Table 1. Distribution of the most and the least used Metacognitive Reading Strategies by the Students

\section{Frequency of Using Metacognitive Reading Strategy by the students
The most frequently used metacognitive strategies by the students before read
I determine my reading purpose (studying, fun, memorizing, etc.)
I check out the conditions of my reading environment like the light, sound,
temperature, place to sit and try to make them suitable for me
I take a quick look at the text to understand its type and subject.
I guess the content of the text based on its images}

The least frequently used metacognitive strategies by the students before reading

$$
\text { I prepare questions in my mind about the subject }
$$

I mentally plan what I will do before, during, and after reading the text,

The most frequently used metacognitive strategies by the students during reading

I try to imagine what is described in the text and try to understand it.

If I get distracted, lose concentration or fall into other thoughts while reading the text, I go back to where I do not understand in the text and read again.

I read slower and more careful the sections I do not understand in the text

I reread the parts that are hard to understand

The least frequently used metacognitive strategies by the students during reading

$$
\text { I take notes about the text. }
$$

I divide the complex sentences in the text into pieces in order to understand them.

The most frequently used metacognitive strategies by the students after reading

$$
\text { I read the text again, if necessary. }
$$

I revise the text.

The least frequently used metacognitive strategies by the students after reading

I evaluate whether or not the title and content of the text are consistent.

$$
\text { I summarize what I read to remember the text }
$$

The most frequently used metacognitive strategies by the students to recall

$$
\text { I underline the important information }
$$

\begin{tabular}{|c|c|c|c|c|c|}
\hline \multicolumn{2}{|c|}{ Never } & \multicolumn{2}{|c|}{ Sometimes } & \multicolumn{2}{|c|}{ Always } \\
\hline $\mathrm{f}$ & $\%$ & $\mathrm{f}$ & $\%$ & $\mathrm{f}$ & $\%$ \\
\hline 20 & 6.5 & 124 & 40.3 & 164 & 53.2 \\
\hline 21 & 6.8 & 98 & 31.8 & 189 & 61.4 \\
\hline 66 & 21.4 & 82 & 26.6 & 160 & 51.9 \\
\hline 45 & 14.6 & 100 & 32.5 & 163 & 52.9 \\
\hline $\mathrm{f}$ & $\%$ & $\mathrm{f}$ & $\%$ & $\mathrm{f}$ & $\%$ \\
\hline 52 & 16.9 & 129 & 41.9 & 127 & 41.2 \\
\hline 61 & 19.8 & 105 & 34.1 & 142 & 46.1 \\
\hline $\mathrm{f}$ & $\%$ & $\mathrm{f}$ & $\%$ & $\mathrm{f}$ & $\%$ \\
\hline 23 & 7.5 & 70 & 22.7 & 205 & 69.8 \\
\hline 27 & 8.8 . & 65 & 21.1 & 216 & 70.1 \\
\hline 23 & 7.5 & 58 & 18.8 & 227 & 73.7 \\
\hline 22 & 7.1 & 73 & 23.7 & 213 & 69.2 \\
\hline $\mathrm{f}$ & $\%$ & $\mathrm{f}$ & $\%$ & $\mathrm{f}$ & $\%$ \\
\hline 75 & 24.4 & 134 & 43.5 & 99 & 32.1 \\
\hline 80 & 26.0 & 125 & 40.6 & 103 & 33.4 \\
\hline $\mathrm{f}$ & $\%$ & $\mathrm{f}$ & $\%$ & $\mathrm{f}$ & $\%$ \\
\hline 36 & 11.7 & 101 & 32.8 & 171 & 55.5 \\
\hline 40 & 13.0 & 97 & 31.5 & 171 & 55.5 \\
\hline $\mathrm{f}$ & $\%$ & $\mathrm{f}$ & $\%$ & $\mathrm{f}$ & $\%$ \\
\hline 49 & 15.9 & 117 & 38.0 & 142 & 46.1 \\
\hline 46 & 14.9 & 115 & 37.3 & 147 & 47.7 \\
\hline $\mathrm{f}$ & $\%$ & $\mathrm{f}$ & $\%$ & $\mathrm{f}$ & $\%$ \\
\hline 50 & 16.2 & 77 & 25.0 & 171 & 55.5 \\
\hline 26 & 8.4 & 90 & 29.2 & 192 & 62.3 \\
\hline $\mathrm{f}$ & $\%$ & $\mathrm{f}$ & $\%$ & $\mathrm{f}$ & $\%$ \\
\hline 80 & 26.0 & 96 & 31.2 & 132 & 42.9 \\
\hline 82 & 26.6 & 98 & 31.8 & 128 & 41.6 \\
\hline
\end{tabular}

I try to imagine what I read in my mind.

The least used metacognitive strategies by the students to recall

I take notes about the text.

I note exactly the parts that I consider important in the text. 
As seen in Table 1, the most frequently used strategy by the students before reading to understand better was "I check out the conditions of my reading environment like the light, sound, temperature, place to sit and try to make them suitable for me" (61.4\%) and the least used strategy was "I prepare questions in my mind about the subject" $(41.2 \%)$. The most frequently used strategy by the students during reading to understand better was "I read slower and more careful the sections I do not understand in the text" (73.7\%). The least frequently used strategy by the students during reading was "I take notes about the text" (32.1\%). The most frequently used strategy by the students after reading to understand better was "I read the text again, if necessary." (55.5\%) and the least frequently used one was "I evaluate whether or not the title and content of the text are consistent" (46.1\%). Furthermore, the most frequently used strategy by the students to recall was "I try to imagine what I read in my mind." (62.3\%) and the least frequently used one was "I take notes about the text" $(42.9 \%)$. Table 2 shows the results related to the group of strategies that the students used most frequently before, during and after reading to understand better and to recall.

Table 2. Descriptive Statistics on Students' Frequencies of Preferring Metacognitive Reading Strategies

\begin{tabular}{ccccc}
\hline Subscales & Mean Variance & $\begin{array}{c}\text { Std. } \\
\text { Deviation }\end{array}$ & Items \\
\hline $\begin{array}{c}\text { Before Reading for Better } \\
\text { Understanding }\end{array}$ & 21.29 & 11.755 & 3.429 & 9 \\
$\begin{array}{c}\text { During Reading for Better } \\
\quad \text { Understanding }\end{array}$ & 57.60 & 79.895 & 8.938 & 24 \\
$\begin{array}{c}\text { After Reading for Better } \\
\text { Understanding }\end{array}$ & 14.28 & 8.047 & 2.837 & 6 \\
$\quad$ For recalling & 20.81 & 17.678 & 4.204 & 9 \\
\hline
\end{tabular}

When Table 2 was examined, it can be asserted that while the most frequently used metacognitive reading strategy was the strategies during reading for better understanding $(\mathrm{x}=57.60)$, the least frequently used one was the strategies after reading for better understanding $(x=14.28)$. Table 3 shows the correlations between the frequencies of using metacognitive reading strategies of the students and non-routine problem solving successes.

Table 3. esults of Correlation Analysis between Fifth Grade Students' Metacognitive Reading Strategies and Non-routine Problem Solving Achievement Test Results ( $\mathrm{N}=308)$

\begin{tabular}{cccccc}
$\begin{array}{c}\text { Subscales } \\
\text { Before Reading for Better } \\
\text { Understanding }\end{array}$ & $\mathbf{1}$ & $\mathbf{2}$ & $\mathbf{3}$ & $\mathbf{4}$ & $\mathbf{5}$ \\
$\begin{array}{c}\text { During Reading for Better } \\
\text { Understanding }\end{array}$ & $.747^{*}$ & 1 & & & \\
$\begin{array}{c}\text { After Reading for Better } \\
\text { Understanding }\end{array}$ & $.607^{*} .821^{*}$ & 1 & & \\
$\begin{array}{c}\text { For recalling } \\
\text { 5. Non-routine Problem } \\
\text { Solving }\end{array}$ & $.570^{*} .799^{*}$ & $.780^{*}$ & 1 & \\
\hline
\end{tabular}

$* \mathrm{p}<0.01$
As seen in Table 3, it can be said that there was a significant correlation between the frequency of using metacognitive reading strategy and non-routine problem-solving skills in fifth grade students. Accordingly, it was observed that the strategies used during reading for better understanding among subscales of frequencies of using metacognitive reading strategies had the highest correlation with the non-routine problem solving achievement $(\mathrm{r}=.53, \mathrm{p}<.01)$; whereas, the lowest correlation was determined to be between the strategies used for recalling and the non-routine problem solving achievement $(\mathrm{r}=.43, \mathrm{p}<.01)$. In addition, Table 4 shows the results about the prediction of non-routine problem solving achievement scores separately with the subscales of the frequencies of using metacognitive reading strategies.

Table 4. Results of Simple Linear Regression Analysis Between the Non-routine Problem Solving Achievement Test and Metacognitive Reading Strategies

\begin{tabular}{|c|c|c|c|c|c|}
\hline Variable & B & $\begin{array}{c}\text { Std. } \\
\text { E }\end{array}$ & B & $\mathbf{t}$ & $\mathbf{p}$ \\
\hline Constant & -5.031 & .884 & & -5.688 & $.000 *$ \\
\hline $\begin{array}{l}\text { Before Reading } \\
\text { for Better } \\
\text { Understanding }\end{array}$ & .348 & .041 & .445 & 8.497 & $.000 *$ \\
\hline $\mathrm{R}=.45$ & $\mathrm{R}^{2}=.20$ & & & & \\
\hline $\mathrm{F}=72.20$ & $\mathrm{p}=.00 *$ & & & & \\
\hline Constant & -6.755 & .867 & & -7.796 & $.000 *$ \\
\hline $\begin{array}{c}\text { During Reading } \\
\text { for Better } \\
\text { Understanding }\end{array}$ & .159 & .015 & .530 & 10.678 & $.000 *$ \\
\hline $\mathrm{R}=.53$ & $\mathrm{R}^{2}=.28$ & & & & \\
\hline $\mathrm{F}=114.02$ & $\mathrm{p}=.00 *$ & & & & \\
\hline Constant & -3.654 & .707 & & -5.166 & $.000 *$ \\
\hline $\begin{array}{c}\text { After Reading for } \\
\text { Better } \\
\text { Understanding }\end{array}$ & .423 & .049 & .454 & 8.714 & $.000 *$ \\
\hline $\mathrm{R}=.454$ & $\mathrm{R}^{2}=.21$ & & & & \\
\hline $\mathrm{F}=75.95$ & $\mathrm{p}=.00 *$ & & & & \\
\hline Constant & -3.329 & .708 & & -4.703 & $.000 *$ \\
\hline For recalling & .275 & .033 & .434 & 8.241 & $.000 *$ \\
\hline $\mathrm{R}=.43$ & $\mathrm{R}^{2}=.19$ & & & & \\
\hline $\mathrm{F}=67.92$ & $\mathrm{p}=.00 *$ & & & & \\
\hline
\end{tabular}

$* \mathrm{p}<.01$

When Table 4 was examined, it was observed that the subscales of frequencies of using metacognitive reading strategies individually predicted non-routine problem solving achievement test scores significantly in terms of the standardized $(\beta)$ coefficient and $t$ value. Accordingly, non-routine problem solving successes were predicted at the rate of $20 \%(\mathrm{R}=.45 ; \mathrm{F}=72.20 ; \mathrm{p}<.01)$ with the strategies used before reading for better understanding, at the rate of $28 \%(\mathrm{R}=.53 ; \mathrm{F}=114.02 ; \mathrm{p}<.01)$ with the strategies used during the reading for better understanding, at rate of $21 \%(\mathrm{R}=.454 ; \mathrm{F}=75.95 ; \mathrm{p}<.01)$ with the strategies used after reading for better understanding, and 
at the rate of $19 \%(\mathrm{R}=.43 ; \mathrm{F}=67.92 ; \mathrm{p}<.01)$ with the strategies used for recalling. Table 5 shows the results about the prediction of non-routine success scores by the subscales of frequencies of using metacognitive reading strategies.

Table 5. Results of Multiple Linear Regression Analysis between the Non-routine Problem Solving Achievement Test and Metacognitive Reading Strategies

\begin{tabular}{|c|c|c|c|c|c|}
\hline Subscale & B & $\begin{array}{c}\text { Std. } \\
\text { E }\end{array}$ & B & $\mathbf{t}$ & $\mathbf{p}$ \\
\hline Constant & -7.127 & .914 & & -7.794 & $.000^{*}$ \\
\hline $\begin{array}{c}\text { Before Reading } \\
\text { for Better } \\
\text { Understanding }\end{array}$ & .089 & .058 & .114 & 1.522 & .129 \\
\hline $\begin{array}{l}\text { During Reading } \\
\text { for Better } \\
\text { Understanding }\end{array}$ & .115 & .034 & .385 & 3.371 & $.001 *$ \\
\hline $\begin{array}{c}\text { After Reading for } \\
\text { Better } \\
\text { Understanding }\end{array}$ & .049 & .087 & .053 & .568 & .571 \\
\hline For Recalling & .013 & .056 & .021 & .232 & .817 \\
\hline $\mathrm{R}=.54$ & $\mathrm{R}^{2}=.29$ & & & & \\
\hline$F=29.18$ & $\mathrm{p}=.00^{*}$ & & & & \\
\hline
\end{tabular}

When Table 5 was examined, it was observed that the independent variables predicted the non-routine problem solving successes $(\mathrm{F}=29.18, \quad \mathrm{p}<.01)$. Independent variables accounted for the non-routine problem solving achievements at the rate of $29 \%\left(\mathrm{R}=.54, \mathrm{R}^{2}=.29\right)$. Furthermore, when the $t$ values about the significance of the regression coefficients were examined, only metacognitive strategies used during reading were said to be an important predictor of non-routine problem solving achievements.

\section{Conclusions and Discussion}

At this stage of this study investigating the correlation between the frequencies of using metacognitive reading strategies and the non-routine problem solving achievement in fifth grade students, the obtained results were discussed and presented within the context of the literature. In this direction, the frequencies of using metacognitive reading strategies by the students were determined first. According to Willian \& Burden, [40], metacognitive strategies are important since they are associated with the mental processes like learning, obtaining, and storing the information. In addition, it is necessary to determine the reading strategies that the students have for supporting the reading skills of the students and developing their reading skills [33]. As a result of the study, it was observed that the students used mostly the strategies during reading and least the strategies after reading. The students used the strategies before reading and for recalling at similar rates. Accordingly, it can be asserted that the students tried to make the physical conditions suitable before reading to understand better and did not make too much mental preparations for reading. They tried to read more slowly and carefully during reading to understand better; whereas, they preferred to take notes about the text less. While the students read the text again and again after reading to understand better, they examined less often the content of the text. Moreover, the students preferred more often to imagine what they read to recall; whereas, they prefer to take notes about the text less. When the relevant literature is examined, it is seen that similar studies about the subject are conducted. For example, Başaran [6] expressed that while fourth grade students frequently used the metacognitive reading strategies before, during, and after the reading, they used the recalling strategies less than the others.

According to another result of the study, it was observed that there was a significant correlation between the frequency of using metacognitive reading strategies by the students and their non-routine problem solving success. It can be said that metacognitive reading strategies are a significant predictor of the non-routine problem solving successes separately and together (before, during, after reading and to recall). According to a similar study, there was a highly significant correlation between the problem solving achievement of primary school students and their reading comprehension skills [36]. It is possible to say that the said results are in parallel with the related literature. Similarly, Ulu, Tertemiz \& Peker [37] determined in their study that the training on problem solving accounted for $11.74 \%$ of the non-routine problem solving achievement; whereas, the training on understanding strategies along with the pretest results accounted for $52.28 \%$ of the change in achievement. Based on this point of view, reading comprehension can be asserted to be significant in increasing effectiveness of solution in problem solving studies.

In addition, Mandacı Şahin \& Kendir [21] determined that the experimental group, to whom how problems can be solved with metacognitive strategies was taught, improved their attitudes towards courses, skills of understanding problem, controlling the process, and being aware, and their reflective thinking skills. It was determined in the study by Meniado [23] that there was no significant correlation between the metacognitive reading strategies and reading comprehension performances of the students. In addition, it was determined in this study that the participants used moderate level of metacognitive reading strategies and the problem solving strategies were the most frequently used strategy. Similarly, Ateş [5] determined that the students used metacognitive strategies in moderate level during reading and their problem solving skills were high. These results showed that metacognitive reading strategies were important in problem solving skills.

One of the limitations of the study is that the participants were selected only from two provinces of 
Turkey (Ankara-Istanbul). In addition, another limitation of the study can be that the study was conducted with only fifth grade students and did not include the other grade students. The following recommendations can be involved by considering these limitations and the study results. When the results of the study were taken into consideration, it was seen that the students' frequencies of using metacognitive reading strategies affected their non-routine problem solving skills. In this section, experimental studies can be carried out for supporting the problems solving skills of the students with training of metacognitive reading strategies. In addition, it was determined in the study that the students used less frequently the strategies after reading. In this respect, the reasons for this situation can be examined in depth with qualitative research designs. It is recommended to plan studies about the correlations between the students' metacognitive reading strategies and different variables such as creative thinking skills, social problem solving skills, and mathematical thinking skills. It is recommended to conduct studies with larger samples by using qualitative and quantitative designs together for the frequencies of using metacognitive reading strategies by primary school students.

\section{REFERENCES}

[1] Akyol, H, \& Kodan, H. (2016). A practice for eliminating reading difficulty: the use of fluent reading strategies. Ondokuz Mayis University Journal of Faculty of Education, $35(2), 7-21$.

[2] Altun, M. (2008). Matematik öğretimi, Aktüel Alfa Akademi, Bursa.

[3] Arslan, Ç. \& Altun, M. (2007). Learning to solve non-routine mathematical problems, Illköretim Online, 6(1), $50-61$.

[4] Artut, P. D., \& Tarım, K. (2006). Investigation of the elementary school students' problem solving levels, problem solving strategies and error types in the non-routıne word problems. Ç. $\ddot{U}$. Sosyal Bilimler Enstitüsü Dergisi, 15 (2), 39-50.

[5] Ateş, A. (2013). Üniversite öğrencilerinin okuma stratejileri üstbilişsel farkındalık düzeyleri, Uluslararası Türkçe Edebiyat Kültür Eğitim Dergisi Sayı: 2(4), 258-273.

[6] Başaran, M. (2013). 4. Sınıf öğrencilerinin üstbilişsel okuma stratejilerini kullanma durumları ve bu stratejilerle okuduğunu anlama arasındaki ilișki, Turkish Studies, 8(8), 225-240.

[7] Baydı, B. (2011). Examining the use of metacognitive reading strategies of students with reading difficulties and their teachers' reading comprehension instruction practices. Education and Science, 36(162), 301-319.

[8] Büyüköztürk, Ș. (2016). Sosyal bilimler için veri analizi el kitabl: İstatistik araştırma deseni SPSS uygulamaları ve yorum. Ankara: Pegem Akademi Yayıncılık.

[9] Büyüköztürk, Ş., Kılıç Çakmak, E., Akgün, Ö. E., Karadeniz, Ş. ve Demirel, F. (2017). Bilimsel araştırma yöntemleri. Ankara: Pegem Akademi.

[10] Cemiloğlu, M. \& Ogur, E. (2016). Okuma öğretiminde biliş ve üst-biliş stratejileri,

UluslararasıHakemliİnsanveSanatAraștırmaları ergisi, 118-137.

[11] [Christenson, L. B., Burke Johnson, R. \& Turner, L. A. (2015). Araştırma yöntemleri: desen ve analiz (A. Aypay, Çev. Ed.). Ankara: Anı Yayıncılık.

[12] Çiftçi, Ö. \& Temizyürek, F. (2008). İlköğretim 5. sinıf öğrencilerinin okuduğunu anlama becerilerinin ölçülmesi. Mustafa Kemal Üniversitesi Sosyal Bilimler Enstitüsü Dergisi, 5(9). 110- 129.

[13] De Hoys, M., Gray, E., \& Simpson, A. (2002). Student's assumptions during problem solving, paper presented at the 2nd International Conference on the Teaching of Mathematics, Crete, July.

[14] Doğan, A. (2013). Üstbiliş ve üstbilişe dayalı öğretim, Middle Eastern and African Journal of Educational Research, 3, 6-20.

[15] Elia, I., Van den Heuvel-Panhuizen, M., \& Kolovou, A. (2009). Exploring strategy use and strategy flexibility in non-routine problem solving by primary school high achievers in mathematics. ZDM Mathematics Education, 41, 605-618.

[16] Fidell, L, S., and Tabachnick, B. (2015). Çok değişkenli istatistiklerin kullanımı. Ankara, Nobel Yayınları.

[17] García, T., Cueli, M., Rodríguez, C., Krawec, J., \& González-Castro, P. (2015). Metacognitive knowledge and skills in students with deep approach to learning. Evidence from mathematical problem solving. Revista de Psicodidáctica, 20(2), 209-226.

[18] Hacker, D. J. ve Dunlosky, J. (2003). Not all metacognition is created equal. New Directions for Teaching and Learning, 95, 73-79.

[19] Hite, S. (2009). Improving problem solving by improving reading skills. Math in the middle institute partnership summative projects for master degree. University of Nebraska - Lincoln.

[20] Kalayc1, Ş. (2016). SPSS Uygulamalı Çok Değişkenli Istatistik Teknikleri, Ankara, Asil Yayınc1lık.

[21] Mandacı Şahin, S. \& Kendir, F. (2013). The effect of using metacognitive strategies for solving geometry problems on students' achievement and attitude, Educational Research and Reviews, 8(19), 1777-1792.

[22] Marchis, I. (2012). Non-routine problems in primary mathematics workbooks from Romania, Acta. Didaktica, Napocensia, 5(3), 49-56.

[23] Meniado, J. C. (2016). Metacognitive reading strategies, motivation, and reading comprehension performance of Saudi EFL students, English Language Teaching, 9(3), 117-129.

[24] Mokhtari, K. \& Reichard, C. A. (2002). Assessing students' 
metacognitive awareness of reading strategies. Journal of Educational Psychology, 94(2), 249-259.

[25] Özsoy, G. (2008). Üstbiliş. Türk Eğitim Bilimleri Dergisi, 6(4), 713-740.

[26] Pammu A., Amir, Z., \& Maasum, T. N. R. T. (2014). Metacognitive reading strategies of less proficient tertiary learners: a case study of EFL learners at a public university in Makassar, Indonesia. Procedia - Social and Behavioral Sciences 118, 357-364.

[27] Patton, M, Q. (2015). Nitel araștırma ve değerlendirme yöntemleri. (M. Bütün ve S. Beşir Demir. Çev. Ed.). Ankara: Pegem Akademi Yayıncılık.

[28] Pesen, C. (2003). Eğitim fakülteleri ve sinıf ögrretmenleri için matematik öğretimi, Ankara: Nobel Yayın Dağıtım.

[29] Phakiti, A. (2003). A closer look at the relationship of cognitive and metacognitive strategy use to EFL reading achievement test performance. Language Testing, 20(1), 26-56.

[30] Polya, G. (1957). How to solve it? Princeton: Princeton University Press.

[31] Schloeglmann, W. (2004). Routines in non-routine problem solving processes, Group for the Psychology of Mathematics Education, 4, 161-168.

[32] Selçuk, Z. (2000). Gelişim ve öğrenme. Ankara: Nobel Yayın-Dağıtım.

[33] Sheorey, R., \& Mokhtari, K. (2001). "Differences in the cognitive awareness of reading strategies among native and non-native readers, System 29(4), 431-449.

[34] Taraban, R., Rynearson, K. \& Kerr, M. (2000). College students' academic performance and self-reports of comprehension strategy use. Reading Psychology, 21(4),
$283-308$.

[35] Tunca, N., \& Alkın-Şahin, S. (2014). Öğretmen adaylarının bilişötesi (üst biliş) öğrenme stratejileri ile akademik öz yeterlik inançları arasındaki ilișki, Anadolu Journal of Educational Sciences International, 4(1), 47-56.

[36] Tuohimaa, P. M., V., Aunola, B., \& Nurmi, J. (2008). The association between mathematical word problems and reading Comprehension. Educational Psychology, 28(4), 409-426.

[37] Ulu, M, Tertemiz, N., \& Peker, M. (2016). Okuduğunu anlama ve problem çözme stratejileri eğitiminin ilköğretim 5. sinif öğrencilerinin rutin olmayan problem çözme başarısına etkisi, Afyon Kocatepe Üniversitesi Sosyal Bilimler Dergisi, 18(2), 303-340.

[38] Ulu, M. (2011). İlköğretim 5. sinıf ögrencilerinin rutin olmayan problemlerde yaptıklart hatalartn belirlenmesi ve giderilmesine yönelik bir uygulama. (Yayımlanmamıs Doktora Tezi) Gazi Üniversitesi Ankara.

[39] Wheatly, G., H. (1991). Enhancing mathematics learning through imagery. Math. Teacher 39, 34-36.

[40] Williams, M., \& Burden, R. L. (1997). Psychology for language teachers: A social constructivist approach. Cambridge: Cambridge University Press.

[41] Yavuz, G., Deringöl, Y., \& Arslan, Ç. (2017). Elementary School Students Perception Levels of Problem Solving Skills. Universal Journal of Educational Research 5(11), 1896-1901.

[42] Yazgan, Y. (2007). Dördüncü ve beşinci sinıf öğrencilerinin rutin olmayan problem çözme stratejileriyle ilgili gözlemler, İlköğretim Online, 6(2), 249-263.

[43] Yıldırım, A. ve Şimşek, H. (2016). Sosyal bilimlerde nitel araştırma yöntemleri. Ankara: Seçkin Yayınları. 